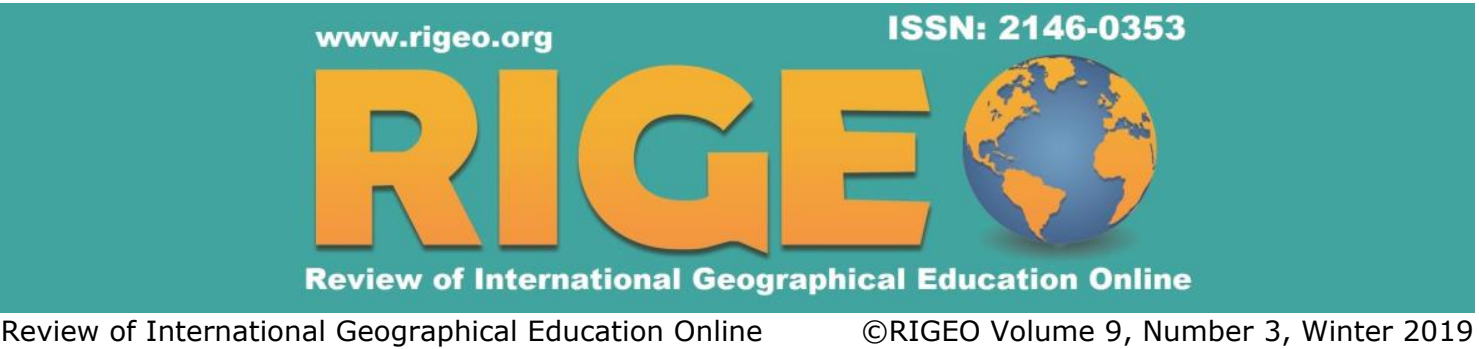

Research Article

Copyright @ RIGEO 2019

To cite this article: Çifçi, T., Dikmenli, Y. (2019). Why Geography Learning: Candidate Teachers' Views for Geography Course. Review of International Geographical Education Online (RIGEO), 9(3), 557-576. Retrieved from http://www.rigeo.org/vol9no3/Number3Winter/RIGEO-V9-N3-4.pdf

DOI:10.33403/rigeo.672979

Submitted: July 1,2018 Revised: February 5, 2019 Accepted: August 1, 2019

\title{
Why Geography Learning: Candidate Teachers' Views for Geography
}

\author{
Taner ÇİFÇَ' ${ }^{1}$ \\ Sivas Cumhuriyet University, Sivas, TURKEY \\ Yurdal DİKMENLi் 2 \\ Kırşehir Ahi Evran University, Kırşehir, TURKEY
}

\begin{abstract}
The aim of this study is to reveal the status of the geography course among other courses as perceived by teacher candidates, the way they use their geographic knowledge in daily life, what their expectations are from geography courses, and to determine their opinions about the necessity of learning geography and their suggestions for teaching geography. The phenomenology design, one of the qualitative research methods, was adopted in the study. The study group consisted of 94 preservice teachers studying in the Social Studies Education and Primary Education Program of the Cumhuriyet University Faculty of Education in the 2017-2018 academic year. While determining the study group, maximum diversity, which is one of the purposive sampling methods, was used and care was taken to make this selected group of interviewed participants to be representative of the department, age and gender proportion of the preservice teachers. Content analysis and descriptive analysis were used together in the interpretation of the data obtained from the interviews with the preservice teachers. The collected data revealed that the majority of the teacher candidates place the geography courses among the top level/important and necessary courses. According to the preservice teachers, learning geography is necessary for the effective national administration and homeland defense, instilling the love for the homeland, associating phenomena with daily life, gaining knowledge about the near and far environments, creating an awareness of co-existence, gaining a general culture, loving and preserving the natural environment, establishing links between natural and human-made formations and between their causes and consequences.
\end{abstract}

Keywords

Geography, Geography Course, Teaching Geography, Preservice Teachers, Learning Necessity

${ }^{1}$ Corresponding author: Associate professor, Sivas Cumhuriyet University, Faculty of Education, Department of Basic Education, Sivas, Turkey, tanercifci[at]gmail.com, ORCID: 0000-0002-2057-7136

${ }^{2}$ Associate professor, Kırşehir Ahi Evran University, Faculty of Education, Department of Basic Education, Kırşehir, Turkey, dikmenliy[at]hotmail.com, ORCID: 0000-0003-3738-3095

(C) Review of International Geographical Education Online

RIGEO 2019

ISSN: 2146-0353

www.rigeo.org 
There is no single and common definition of geography in the literature. In general, geography is defined as "the science that analyzes the natural, social and economic phenomena of the earth by relating them to human beings" (Izbirak, 1992), as "a science that examines the natural, human, and economic phenomena on the geographic earth by establishing relations with human beings," (Doğanay, 1993), and as "a science that examines the natural characteristics of the human environment, the human-natural environment interaction, and the social and economic activities of human beings according to the principles of distribution, causality and commitment" (Şahin, 2013). Bu tanımların hemen hepsinde ortak olan insan ve doğal çevre ile bunlar aralarındaki ilişkilerdir. Common to all of these definitions are the human and natural environment and their relationships. As such, geography acts as a beam between the human and natural environment and reflects some of the world's knowledge and insights as light thanks to its illuminating aspect (Slater, 1994).

Although geography is generally classified as a social science, it is a multidimensional discipline of science with direct or indirect relationships with almost all other disciplines of science. Geography has a unifying effect between natural and human sciences as well. Therefore, geography is in constant dialogue with the other disciplines. Geography provides people with the necessary information for a life in harmony with the nature. That is why all people living on earth need to have this information. While living on the earth, we are affected by its characteristics and affect it with all the activities we perform. No matter how we continue our lives, no matter what we engage in, we need geographic information to be minimally harmed by the nature, to be able to dominate it and be productive when necessary, to compete, to make appropriate choices, to take control of our own lives, and to take preventive measures against the negative and destructive effects of the nature. Regulating and planning the lives and activities of people, the institutions and professions that require expertise also need geographical information (Demirci, Sekin \& Ünlü, 2002). However, a large section of society sees geography as a science that only gives general culture (Doğanay, 1989).

The developed countries try to develop effective solutions to problems by using geography science and geographers in almost all fields, especially regarding the social, cultural, economic and environmental issues. In addition, in these countries, geography is one of the most popular courses in the primary and secondary education (Demirci, 2004). However, the general opinion in Turkey has it that students view geography courses as as a series of boring theoretical lectures that are full of geographical information to be memorized, which does not relate to their daily life. The curriculum, textbooks, attitudes of the teachers, the methods used in the courses, and the geographical equipment and material deficiencies play an important role in the formation of this perception. An important task that can be undertaken to save geography from this misperception is to relate the geographical issues to the real life by using some new techniques in the teaching process (Doğanay, 2002). 
In order to understand the events in life, to take preventive measures against the problems, and to become an effective citizen, a good geographical knowledge is needed. For this reason, it is aimed to provide students with eight basic skills: geographical observation, working in the field, geographical inquiry, perception of time, perception of change and continuity, mapping skills, preparing tables, graphs and diagrams, and using evidence (MEB, 2017). In addition, geography has a political power because it is the source of national culture besides guiding the political leaders. Without geography, we cannot have a homeland where we feel belonging and which we consider sacred. Without a homeland, there cannot be a state, nor there national self, national culture and civilization. Therefore, all modern nations have given priority to the geography curricula and placed an emphasis on their own countries in these curricula. In this respect, geography is an important science that nurtures national and universal culture and gives public officials the ability to make international comparisons and inferences (Doğanay \& Doğanay, 2015). Governments focus on improving the learning outcomes in the key issues. Therefore, due to the governments' increasing belief about the importance of geography regarding a wide range of issues, the geography-related course subjects have been included in various curricula (Bent, Bakx \& Brok, 2016).

In fact, people need various types of information to be able to raise their living standards. An important part of this information is geographic. Because the information taught in geography classes' concerns people's lives in various ways and makes their lives easier. In addition, geography knowledge is very important in finding locations accurately, using maps properly, strengthening the love of homeland and citizenship, governing a nation effectively, making successful comparisons with other countries, and national defense (Şahin, 2013; Girgin, 2001; Tanrikulu, 2018). In this respect, young people who lack adequate knowledge of geography will be caught unprepared to meet the new needs created by the increasing globalization (Reinfried \& Hertig, 2011).

Unfortunately, the importance and necessity of learning geography in Turkey seems to be not adequately recognized. This is because the key role played by the subject of geography in areas such as national unity, management, planning (physical, economic, social and political), implementation, and solution-generation seems not yet sufficiently understood. In addition, the existing laws in Turkey have not yet clearly defined the profession of the "geographer," and Turkish geographers are not yet in their professionally deserved position (Özturk Demirbaş \& Dikmenli, 2016). According to the students' perceptions revealed by the research, the importance of the geography course is quite low when compared with the other courses (Sack \& Petersen, 1998). In fact, geography should play a critical role in preparing young people to face their responsibilities and developing a critical understanding of the rapidly changing world (Eyles, 1989).

It is important for individuals to become aware of the necessity of learning geography and to know the impact of geography on their lives to help geography education to rise to the position it deserves and to be more effective. To fully appreciate the necessity of learning geography, it is necessary to be aware of geographical 
knowledge, what it contributes to us, what skills it equips us with, and where and for what use it can be employed. Although there are some studies under different names, applying different methods and levels in the literature (Akınoğlu, 2005; Girgin, 2001; Kocalar \& Demirkaya, 2014; Eyles, 1989; Ünlü \& Alkış, 2006), no study was found to answer the problems and sub-problems of the current research. This study aims to determine the place of the geography course among the other courses according to the preservice teachers, how they use geographic knowledge in daily life, what their expectations are from the geography courses, their opinions about the necessity of geography learning, and their suggestions for geography teaching.

\section{Study Design}

\section{Methodology}

The phenomenology design, one of the qualitative research methods, was used to determine the opinions of preservice teachers about the necessity of learning geography. The purpose of this design is to fully describe how the participants experience the phenomenon under focus. Phenomenology focuses on the facts that people are actually aware of but do not have an in-depth and detailed understanding about (Yildirım \& Şimşek, 2013). Therefore, it was deemed appropriate to use the phenomenology design in this study.

\section{Study group}

The study group consists of 94 preservice teachers studying in the Social Studies and Primary Education Departments who took geography courses in Cumhuriyet University Faculty of Education in the 2017-2018 academic year. While determining the study group of the research, maximum diversity, which is one of the purposive sampling methods, was used and care was taken to select the preservice teachers to represent the overall research population proportionally according to the department, age and gender. Purposive sampling allows researchers to work more deeply in cases with extensive information (Yıldırım \& Şimşek, 2013). Teacher candidates studying at Cumhuriyet University were preferred because of the fact that the study group was conveniently accessible, enabling the acceleration of the research process. The distribution of the participants according to certain criteria is given in Table 1.

Table 1

Study Group

\begin{tabular}{llllll}
\hline Gender & n & \% & Undergraduate Major (Program) & n & \% \\
\hline Male & 40 & 42,6 & Social Studies Education & 45 & 47,9 \\
Female & 54 & 57,4 & Primary Education & 49 & 52,1 \\
\hline Total & 94 & 100 & & 94 & 100 \\
\hline
\end{tabular}

\section{Data Collection}

Aiming to obtain in-depth data, the data collection tool of this phenomenological study is the interview. The interview method, which is advantageous in terms of ensuring the participant to respond without consulting with someone else, preserving 
the individuality in the answers, and confirmation of the data source, is more valid than the data obtained through the survey method (Karasar, 2015).

The opinions of a faculty member specialized in qualitative research methods were obtained on the interview questions to be asked to the participants, and a piloting was conducted with the questions shaped according to the expert opinion. In the piloting process, which was conducted to measure the suitability and adequacy of the questions in the interview form, 20 preservice teachers who were not among the participants were interviewed and seven open-ended questions were posed to them. These open-ended questions which aim to explain the pre-service teachers' views about the geography course and the necessity of learning geography are given below:

1-When you think of the geography courses together with other courses, where/how do you position them?

2-What are your expectations from the geography courses?

3-Did the geography lessons meet your expectations?

4-How often do you use your geography knowledge in daily life?

5- In which situations/fields do you use your geography knowledge?

6- What are your views on the necessity of learning geography?

7-What are your suggestions for teaching geography?

The official research permissions necessary to elicit the opinions of preservice teachers were obtained from the faculty administration. The preservice teachers to form the study group were determined on a voluntary basis, which helped increase the validity and reliability of the study. Before starting the interview, the participants were given the necessary information about the purpose of the interview and were asked not to share any personal information other than the required information.

\section{Data Analysis}

The content analysis and descriptive analysis were used together in the interpretation of the data obtained from the interviews with the preservice teachers. The content analysis combines the similar data within the framework of certain concepts and themes, and these are interpreted by making them more understandable for the reader (Yıldırım \& Şimşek, 2013). With this method, which is used in both qualitative and quantitative analyses, and also referred to as "text analysis" in the literature, it is important to perform evaluations about phenomena and facts by categorizing words according to their frequency (Bakan \& Bakan, 2017). The content analysis was used to convert the data obtained through the interviews into numerical data. Additionally, the descriptive analysis was used to make the findings more organized and comprehensible. The most prominent feature of the descriptive analysis is the inclusion of "direct quotations" (Kesten \& Özdemir, 2010). The descriptive analysis aims to present the numerous disordered results to the reader in a systematic and interpreted manner (Yıldırım \& Şimşek, 2013). Teacher candidates who participated in the study were coded as P1, P2,....., P94, and thus, their personal information was kept confidential. 
The data were coded by two field experts. The reliability $=$ Consensus $/$ Consensus + Disagreement $\mathrm{x} 100$ formula was applied on the codings made by both experts to find out the reliability (Miles \& Huberman, 1994). The interrater reliability between the two encoders was calculated to be $96 \%$. Since $70 \%$ or higher correlation is considered sufficient (Şencan, 2005), the adequate data analysis reliability was achieved.

\section{Results}

In this section, the results and comments about the problems and sub-problems of the study are given. Teacher candidates were first asked to indicate where and how they placed geography courses when they compared them with other courses. The results related to the preservice teachers' opinions are given in Table 2.

Table 2

Preservice Teachers' Perceptions on Where and How to Position Geography Lessons

\begin{tabular}{lcc}
\hline Degrees & f & \% \\
\hline High/ Important and necessary & 73 & 78 \\
Average/ Partially Important and necessary & 20 & 21 \\
Low/ Unimportant and unnecessary & 1 & 1 \\
Total & 94 & 100
\end{tabular}

As can be seen in Table 2, when they were asked where and how they position the geography courses compared to the other courses, $78 \%$ (73) of the preservice teachers thought that they were among the most important and necessary courses, and $20 \%$ (21) thought that the geography courses were partially important and necessary. $1 \%$ (1) reported that the geography courses were insignificant and unnecessary compared to the other courses. Accordingly, it can be concluded that the majority of the preservice teachers perceive the geography courses as important and necessary compared to the other courses. Some preservice teachers' opinions can be quoted as follows: "I think that the geography course expands the horizon of people especially in terms of introducing the environment and the world in which they live. I find it more important than other courses because we use it in every area of life (P33)".

"Essentially, all sciences are interrelated and complement each other. The geography course is the application area of many courses based on theoretical knowledge. For example, even the development of the science of geometry is linked to the geography, as in ancient Egypt people re-drew of the borders after the overflow of the Nile. That's why I find geography more important P50)". "Geography is a subject that everyone should know about, it is related to daily life, but I think that no lesson can be separated from each other and that they are all important (P12)".

When the opinions of the teacher candidates are examined, it is evident that they find geography courses important because they regard them as a practical discipline that includes information used in daily life. In addition, transferring the knowledge acquired 
through the geography lessons to their daily lives encourages preservice teachers to have a positive point of view towards the geography courses.

The results obtained from the opinions of the preservice teachers about what they expect from the geography courses are given in Table 3 below.

Table 3

Preservice Teachers' Expectations from the Geography Courses

\begin{tabular}{lcc}
\hline Expectations & f & \% \\
\hline Local and global knowledge & 56 & 34 \\
Environmental awareness and knowledge & 38 & 23 \\
General culture knowledge & 26 & 16 \\
Subject-specific (disciplinary) knowledge & 20 & 12 \\
Life knowledge & 12 & 8 \\
The course where technology and field work are & 12 & 7 \\
applied & & 100 \\
\hline Total & 164 & \\
\hline
\end{tabular}

Looking at Table 3, where the preservice teachers' expectations from the geography courses are presented, it can be seen that $34 \%(\mathrm{n}=56)$ expect to gain local and world geography knowledge, $23 \%(\mathrm{n}=38)$ expect to gain environmental awareness and knowledge, $16 \%(\mathrm{n}=26)$ expect general cultural knowledge, 12\% $(\mathrm{n}=20)$ expect disciplinary knowledge 8\% $(\mathrm{n}=12)$ expect to gain knowledge of life, and 7\% $(\mathrm{n}=12)$ state that technological equipment is used and fieldwork is performed. The views of some of the preservice teachers are quoted below.

"The geography course should first teach us about our immediate environment and then the world. In short, the geography education should be from personal to general. Because people cannot know about the places, they do not see without knowing their immediate surroundings, we need to learn about our world. This is because I don't think our horizons can be broadened only by knowing where we live. Especially as a preservice teacher, we need to know about the world (P 3)."

"I would like to be able to explain the natural phenomena that I see around me through geography and to be aware of things that I have not noticed before. To protect the environment and leave a livable environment for future generations, we need to understand the language of the environment. The geography course should give us information about the environment and at the same time make us understand its importance (P 33).”

"I expect my general culture to grow thanks to the geography course, and I would like to be able to answer questions when people with less knowledge ask me. I should be able to respond easily, especially when my students ask me for help on a 
geographical issue. In addition, I would like to learn the necessary information to help me survive in all kinds of geographic conditions in various locations, if necessary (P 52)." "Geography is a science that has always interested me. However, I think that it is important not to teach geography in a superficial way but in depth (P 46)."

"I expect the geography lessons to inform me about everything in my daily life, from what kind of weather I will encounter when I go to another city, to the growing conditions of plant species. I think that the knowledge of geography will help people in almost every aspect of life. Therefore, I would like to be able to explain what I have encountered in new environments or in my own environment with the information I have gained through the geography lessons (P 31)."

"I want geography to be taught in more interesting ways, not just by learning the textbook information. I think geography is the most helpful course for field research and trips. Therefore, I would like to make field trips as part of the geography lessons. This way, I think that the geography information learned will be made more permanent and understandable. I also think that it is important for geography to benefit from technology because I can't visualize some of the geography concepts in the books or I misrepresent them in my mind (P 33)."

Most of the preservice teachers in the study group expect to have knowledge about their own environment and the world. According to the teacher candidates, it will be more useful to first learn about their environment and then to learn about the world. In addition, they want the information given in the geography lessons not only to be limited to be useful for the exams but also to prepare them for life in many areas such as general culture and environmental knowledge and awareness. The preservice teachers, who also have some expectations about the teaching of geography lessons, think that the geography lessons should be taught in a way that benefits more frequently from technology and field trips, not through simple lecturing that depends on the textbooks.

Table 4

Preservice Teachers' Opinions on Whether Geography Lessons Have Met Their Expectations

\begin{tabular}{lll}
\hline Level of Meeting & f & \% \\
\hline Yes & 58 & 62 \\
Partially & 27 & 28 \\
No & 9 & 10 \\
\hline Total & 94 & 100 \\
\hline
\end{tabular}

As can be seen in Table 4, 62\% $(n=58)$ of them affirmed that the geography lessons met their expectations, $28 \% \quad(\mathrm{n}=27)$ reported that the lessons partially met their expectations, and 10\% ( $\mathrm{n}=9)$ were completely negative in their response. Some of their opinions are as quoted below: “Although I didn't know everything about geography, I found that overall, my expectations were met. I think now I have enough knowledge of geography to answer my students' questions when I become a teacher (P92)." 
"As I studied geography, I realized that I did not know the many beauties in our country and how beautiful the country I lived in is. As I can explain what I see around during my travels with my geography knowledge, I realize that I have gradually met my expectations (P39)." "I can say that they have rarely met my expectations because even less important subjects are given 5-6 hours (a week) and the geography is taught only for 2 hours. This time is not (long) enough for us (P38)." "So far, our geography lessons have always been based on memorization, and I have always focused on the exams. The information in the lessons has always been just theoretical. So, I could not get my expectations met (P4)."

The majority of the preservice teachers in the study group think that their geography education has so far met their expectations. However, there are also some preservice teachers who think that the geography lessons have not met their expectations. It was found out that the preservice teachers who think that their expectations have not been met, think so because of the excessive focus of the geography lessons on theoretical content.

Table 5

Preservice Teachers' Views on the Frequency of Using Geographical Knowledge in Daily Life

\begin{tabular}{llr}
\hline Frequency & f & \% \\
\hline Often & 45 & 48 \\
Sometimes & 21 & 22 \\
Always & 15 & 16 \\
Seldom & 10 & 11 \\
Never & 3 & 3 \\
\hline Total & 94 & 100 \\
\hline
\end{tabular}

As can be seen in Table 5, when the teacher candidates were asked how often they used their geography knowledge in daily life, $48 \%(n=45)$ of the then reported using it frequently, while $22 \%(\mathrm{n}=21)$ of them used it sometimes, $16 \%(\mathrm{n}=15)$ always, $11 \%$ $(\mathrm{n}=10)$ rarely, and 3\% $(\mathrm{n}=3)$ stated that they never used geography knowledge in their daily lives. Some of the preservice teachers' views can be directly quoted as follows:

"Of course, I do. In fact, there are situations that can be explained by geography knowledge everywhere, but I can use my knowledge of geography on topics such as interaction witht the natural environment, recognizing plants, recognizing ecosystems, and commenting on the climate when I go to a new place (P94)." "I can't always use it because I've learned my theoretical knowledge theoretically, but sometimes there are situations in which I can use it (P4)."

"Life itself consists of geography, so I think I use my knowledge in every way. It has an important place in my life both because I am studying away from my home city and because I am a daughter of a farmer (P 51)." "Not often, but I use it when I go to a new place or when I am with friends (P 68)." "I can't use my geography knowledge because I have an ordinary life (P50)." 
Nearly half $(48 \%)$ of the preservice teachers stated that they used their geography knowledge frequently in their daily life. However, $3 \%$ of the preservice teachers in the study group stated that they never used geography knowledge in their daily life. As indicated by these findings, these preservice teachers' utilization of geography knowledge in daily life is quite high.

Table 6

Preservice Teachers' Views on the Situations in which they Use Geographical Knowledge

\begin{tabular}{lll}
\hline Situations & f & \% \\
\hline Interpreting environmental issues & 37 & 26 \\
Interpreting climate and weather issues & 34 & 24 \\
Interpreting topography and vegetation issues & 30 & 21 \\
Interpreting cultural issues & 27 & 19 \\
Interpreting directional and positional data & 14 & 10 \\
\hline Total & 142 & 100 \\
\hline
\end{tabular}

When the preservice teachers were asked what geography knowledge they used in daily life, $26 \%(\mathrm{n}=37)$ of them reported that they used it in interpreting environmental issues, $24 \%(\mathrm{n}=34)$ in interpreting climate and weather events, $21 \%$ in interpreting issues related to topography and vegetation, $19 \%(\mathrm{n}=27)$ stated that they used their geography knowledge in understanding and interpreting cultural issues and 10\% $(\mathrm{n}=14)$ interpreting directional and positional information.

According to the findings based on the results, even though the most frequently used field of application for geography in the daily life of preservice teachers is the interpretation of environmental issues, the rate of using geographical knowledge in other cases is quite high as well. In order to better explain this situation, some staements of the preservice teachers are quoted below.

"Geography actually is the life itself. Sometimes we use geography knowledge without being aware of it. I use my knowledge of geography to explain the events that I encounter in my immediate environment. But, in fact, in many cases we apply our geography knowledge (P54)."

"I use my geography knowledge especially when going to different cities. For example, while going to Didim and Sivas, I'm making preparations accordingly. When I go to a new place, I get prepared by considering the information I have about its geographical location, region, climate, and so on (P35)."

"To give a very simple example, I can recognize the tree species around me. My knowledge comes in handy because my family is already engaged in farming. I also like to be able to explain what I have encountered in new environments. I think I've seen more than other people (P4)."

"I can give answers when discussing something with my friends or when the younger ones ask me something. I can feel that my knowledge of geography has broadened my 
horizon in other areas as well. I can bring more logical and scientific explanations to the events happening around me (P68)." "Of course, I do. For example, looking at the sun I can find my direction. I can infer my location (P3)."

As stated by one of the pre-service teachers, people use their geography knowledge many times in their daily lives and often they are not even aware of it. Based on the fact that the frequency of use of the situations is close to each other, it can be interpreted that geography knowledge is utilized in a wide variety of ways in the daily life.

Table 7

Preservice Teachers' Views on the Necessity of Learning Geography

\begin{tabular}{lll}
\hline Statements & f & $\mathbf{\%}$ \\
\hline In governing the nation and defending the homeland & 51 & 37 \\
In gaining the love for the homeland & 19 & 14 \\
In relating the phenomena with daily life & 18 & 13 \\
In knowing the near and far locations & 18 & 13 \\
In creating an awareness of co-existence & 13 & 9 \\
In gaining general culture & 10 & 7 \\
In loving and protecting the nature & 5 & 4 \\
In establishing links between natural and social formations and their & 4 & 3 \\
causes and effects & & \\
\hline Total & 138 & 100 \\
\hline
\end{tabular}

The teacher candidates who participated in the study gave various answers when asked why it was necessary to learn geography. $37 \%(n=51)$ of the teacher candidates responded that geography was essential for governing the country and defense of the homeland, 14\% ( $\mathrm{n}=19)$ stated that it was needed to gain the love of homeland, 13\% stressed gaining the ability to relate the events tho those that occurred in daily life, $13 \%$ $(n=18)$ pointed out the need for geography in being informed about the near and distant environments, 9\% $(n=13)$ pointed at the awareness of co-existence, $7 \%(n=10)$ at the general culture, $4 \%(n=5)$ at the love and protection of the nature, and 3\% $(n=4)$ pointed out that learning geography was necessary to establish a link between the natural and social formations and their causes and effects. The views expressed by some of the preservice teachers are quoted below:

"We were taught that we cannot develop without knowing our homeland and that our love of the country cannot develop without learning geography, so it is very important, which I agree. In addition, having information about our country will affect our decisions. Because our homeland will be entrusted to us in the future and our decisions will be important. Thanks to my geography knowledge, I have learned how rich a country we are and how important it is to protect and develop our country (P50)."

"Geography lessons are the most effective ones in teaching how to appreciate the beauties of our homeland. I have realized that if a person loves something he or she 
doesn't know, it doesn't mean anything. As we discover more about our country thanks to the geography lessons, we realize how beautiful our homeland is (P12)."

"I think that geography is in every sphere of life, even life itself, so it is important to learn geography. We were taught that we will enjoy life as we explain the events, we see around us bu using our knowledge of geography (P28)."

"I have learned that in order to understand what we see around us, we need geography, we need it to understand the earth formations, mountains and lakes. I also feel that I can better understand the developments in the world with my knowledge of geography (P 93).”

"In the geography lessons, it was emphasized that it is important to learn that this world is a living space not only for us but also for all other living things. We have learned that it is possible for all living beings in nature to live together peacefully by learning geography (P66)." "Geography is involved in every aspect of life and makes our lives easier so we, especially teachers, have to master the geography (P3)."

"I think the most important aim of the geography courses is teaching us about the nature. Our environment and the whole world have been entrusted to us. That is why we must protect and love our geography. Geography is the most important support we have to achieve this (P32)." "Through geography lessons, we can learn that everything we see in nature has a reason and these reasons are connected to each other like a chain. Therefore, geography is one of the most important subjects (P48)."

Most of the preservice teachers who participated in the study think that learning geography is necessary due to its role in fostering the love of homeland and raising an awareness to protect it. According to teacher candidates, love of homeland and awareness of homeland protection can only be instilled by knowing the homeland. In addition, teacher candidates emphasized the necessity of the geography course in order to accurately interpret the phenomena occurring in their environment and the whole world. They stated that they were able to interpret the phenomena better thanks to their geography lessons and that their approach towards nature and all living things in the nature has changed.

Table 8

Preservice Teachers' Suggestions for Teaching Geography

\begin{tabular}{lll}
\hline Suggestions & f & \% \\
\hline Students should be more active in classes & 36 & 38 \\
Content must be reinforced with field trips and out-of-school learning & 32 & 34 \\
3D content and virtual environments should be created by using technology & 15 & 16 \\
to enhance the course content & & \\
Special classrooms should be formed in schools to teach geography & 11 & 12 \\
\hline Total & 94 & 100 \\
\hline
\end{tabular}


The preservice teachers who participated in the study were asked to state their suggestions for geography teaching, if any, which were then categorized into four themes. $38 \%(n=36)$ of the preservice teachers stated that students should be more active in the lessons, 30\% ( $n=30)$ stressed that the geography course content should be applied and reinforced with field trips in the nature and enabling out-of-school learning, $16 \%$ $(n=15)$ suggested that it should be enriched by creating 3D images and virtual environments using technology, and $12 \%(\mathrm{n}=11)$ stated that special classrooms should be set up to teach geography in schools. The views of some of the preservice teachers are as follows:

"Although it is a course based on practice and experiential learning, the geography lessons are always based on memorization which always turns students off. I think it might be more fun if students are active in geography. Geography lessons should stop being lessons in which the student just sits and takes notes (P50)."

"Geography lessons should be learned with real life examples, not just textbooks. Therefore, nature trips should be organized frequently so that teachers can better explain the (natural) events. We can also grasp (the course content) better because we gain hands-on experience (P90)."

"Now technology is very effective in education as in all areas of life. However, when we look at the courses that benefit from technology, we see that it is generally used to teach numerical courses such as mathematics faster. Geography is the subject where technology is the most needed because we are trying to get to know the world through geography. We may not have an idea about everything, but (our ideas) would be clearer and more understandable, especially if three-dimensional concepts were shown using technology. I also think it would be more fun and engaging (P66)."

"It would be better if we did not study the geography subject in standard classes, but in specially created classrooms such as science laboratories. We should be able to access material for every subject in an environment where maps and technological products are available (P24)."

Based on these findings, it can be concluded that the teacher candidates complain about passive students, rote education and inadequate out-of-school activities in the geography classes. In addition, students are expected to reinforce what they have learned in the lessons through nature (field) trips, to benefit more from technology and thus to be able to get help in the areas they have difficulty in describing and to study in the geography laboratories, especially in the classrooms specifically set up for this purpose.

\section{Conclusion and Discussion}

In this study, which aims to examine preservice teachers' opinions about where and how they position the geography course compared to the other courses, their expectations from the geography course, to what degree this course has met their expectations, their frequency of using geographical knowledge in daily life, the 
situations they use it, the necessity of learning geography, and their suggestions on teaching of geography, the following conclusions were reached.

Regarding how the teacher candidates compare the geography course with the other courses, it was determined that the majority of them ranks it as a highly important and necessary course, and some rank it as partially important and moderately necessary. Geography finds a place for itself among the science and social sciences and takes on a unifying role (Kızılçaoğlu, 2006). In addition, since geography is not associated only with science, but is more or less connected with all the scientific disciplines, it is labeled as "a community of sciences" (Elibüyük, 2000). For this reason, each sub-science of geography is related to a science discipline that is closer to another and exchanges information with it. For example, it is undeniable that a person without knowledge of chemistry will fail to understand the topography of the city of Kars, a person without knowledge of physics cannot understand the erosion, transport and accumulation activities of external forces, and a person without knowledge of biology cannot understand the ecosystem. Furthermore, it is impossible for a person without geography knowledge to interpret climate issues, daily weather events, solar system, movements of the Earth, and their consequences. Therefore, the importance of geography comes from its interdisciplinary position. Moreover, most people see it as an important and necessary course because they realize that they can find something that interests them in geography. As stated by Johnston (1985), geography contains information about the world, the home of man. Thus, geography is an upper-level discipline and an essential course since the geography courses cover all the subjects that concern people and the world. It can be argued that the geography course is critical for people to understand the events and phenomena that occur in their environment and to interpret the whole world for their own benefit. However, although this is the case, Sack and Petersen (1998) found that the geography course is ranked quite low in student assessments compared to other courses. This may have stemmed from the variations in perception of the geography course across countries, times or study groups. In addition, it is known that those who are not interested in geography have similar criticisms of geography.

When the expectations of the preservice teachers from the geography course were examined, it was concluded that it was a course where gaining knowledge about the local and global environment, gaining environmental awareness and knowledge, gaining general cultural knowledge, gaining field knowledge, gaining knowledge of life, using technological infrastructure and field studies were emphasized. The findings of some other studies support this conclusion as well. Previous research has also reported that the geography course helps create environmental awareness (Aydın, Kaya \& Coşkun, 2011; Aydın, 2012; Taşlı Keçeci, 2010).

A closer analysis of the preservice teachers' opinions about whether the geography lessons they had been taught were up to their expectations, most of them were found to affirm that their expectations were indeed met. However, some preservice teachers thought the opposite was the case. It can be said that the preservice teachers who reported that their expectations about geography courses were not met, may have been 
of this opinion because of the excessive theoretical content of the courses. Coşkun's (2004) study supports such a conclusion because, when the master's and doctoral theses are examined, it can be seen that geography teachers cannot give up the traditional lecturing and the question-and-answer methods, or they fail to adopt new methods and techniques. Effective and permanent learning can eliminate this negative perception of the geography course.

An examination of the preservice teachers' opinions about how often they use their geography knowledge in daily life led to the conclusion that about half of them use it frequently, while some use it occasionally, always, rarely, and never in their daily lives. Essentially, we use our geographical knowledge in our daily lives and make decisions based on this knowledge (Barth and Demirtas, 1997). Some studies support these findings and demonstrate that students use and apply the knowledge they have learned in their geography lessons in their daily lives (Aydın, 2011; Aydın, 2012; Kenger, 2010; Tomal, 2009). In a study conducted by Aydin (2012), some of the students asked their teachers to relate the information they learned in the geography lessons with daily life and give more examples from daily life. Knowingly or unknowingly, every individual uses the geography knowledge to some extent, whether this knowledge is labeled as geographical knowledge or the knowledge obtained from lived experiences. Since the beginning of human existence in the natural environment, the humankind has constantly struggled to cope with natural conditions and strived to survive. To be able to live and improve their quality of life, people constantly apply pressure on the nature and look for ways to benefit more from it. Throughout this process, people try to establish a social, economic and cultural environment by using their geographical knowledge. Moreover, noone can deny that there is a piece of geography knowledge involved in the answers to what we eat, what we wear, how we live, what we produce, where and how we go. Therefore, we can say that people use geographical information consciously or unconsciously.

Analyzing the preservice teachers' opinions about their use of the geography knowledge, it was concluded that they benefited from their geography knowledge in interpreting environmental issues, interpreting climate and weather events, interpreting issues related to topography and vegetation, understanding and interpreting cultural issues, and interpreting directional and positional information. According to the results, although the geography knowledge is most frequently applied for the interpretation of the environmental issues, the rate of using the geography knowledge in other cases is also quite high. As pointed out by a preservice teacher, in fact, people use this knowledge many times in their daily lives and most of the time they are not even aware of it. Based on the fact that the frequency of using geographical knowledge for various situations is similar, it can be interpreted that this knowledge is utilized in various aspects of the daily life.

Analyzing the views of the teacher candidates about the necessity of learning geography revealed that they thought that geography was essential in the governing the nation and defending the homeland, gaining the love of homeland, relating events to 
daily life, knowing the near and distant environments, creating an awareness of living together, gaining a general culture, loving and protecting the natural environment, and protecting the natural and human environment, and linking the reasons and consequences of natural and social events. Evidently, it is necessary to know the homeland in order for the love of homeland and the deep sense of duty to protect it to be formed, which is only possible with the knowledge of geography. Without being informed about their homeland, people cannot be expected to make sacrifices for it or expected to love it from the bottom of their hearts, developing a sense to protect it. Doğanay and Zaman (2002) emphasize that as they learn about every aspect of their country, individuals' love for their countries grow and their commitment to the homeland gets stronger. Indeed, political and military sciences such as strategy, geostrategy and geopolitics, which contribute to the defense of the country and play an active role in the development of love of the homeland, are actually built on the science of geography. State administrators also need to be successful in governing the country, to be able to diagnose the social and economic problems of the country, and to recognize the characteristics of the regions where they are expected to produce solutions (Doğanay \& Zaman, 2002). Ortaylı (2013) asserts that talking about geopolitical and geostrategic issues and attempting to shape international relations without knowing geography will not work; on the contrary, it will make the matters worse, and such ignorant people may get easily stuck in the quagmire in this great region. Similar statements are also found in the literature. The necessity of learning geography is evident in finding locations and using maps, strengthening the love of homeland and citizenship, state administration, comparing countries, having information about world problems, organizing the knowledge about the world, land use, preparation of development plans, environmental awareness, development of natural and human systems and change in the world, and to understand new events in the world and the events during the wars (Şahin, 2013; Girgin, 2001). As Lacoste (1998) puts it, geography primarily serves waging wars. This does not only mean that geography is useful only for military operations. It is used not only against the possibility of war against the enemy, but also to regulate the regions in order to better control the people on which the state organization uses force because geography is primarily a strategic tool for political and military applications. Geography appears chaotic at first glance, requiring numerous pieces of information to be stitched together. If this information does not go beyond the fact that it is fragmented, the reasons and importance of their existence cannot be fully understood. All this makes geography necessary for the managers of state organizations. It is clear that synthesizing and making sense of geographic information is a strategic knowledge and power (Lacoste, 1998). As such, learning geography is vital, both personally and nationally. It can be argued that learning geography is vital to protect national interests, to discover the assets of the country, and to use these assets for the advantage of the country, just as personal life is regulated according to the characteristics of a particular geographical context. The statements quoted above about learning geography strongly supports this conclusion. 
The preservice teachers' suggestions for teaching geography were grouped into four themes. From the most frequent to the least, these themes are as follows: students should be more active in the lessons, the lessons should be consolidated through nature trips and out-of-school learning, the course content should be enriched by using technology to create 3D images and virtual environments, and special classrooms should be created for teaching geography. Based on these findings, it can be concluded that the teacher candidates complain about passive students, rote learning, and lack of adequate out-of-school learning experiences in the geography classes. Because lecturing in the class in the traditional way does not solve the problems, it is necessary to show the students the applications and the solutions these applications bring to the problems in life or to give students the opportunities they need for their own discovery of these solutions (Demirci, 2005). In order to achieve this, students should be provided with the opportunities to reinforce what they have learned in the lessons through field trips in the nature, opportunities to get help from technology to help them visualize the highly abstract or complex concepts, and to study in geography laboratories or in the field that are different from their traditional classroom environment (Dikmenli \& Çifçi, 2016; Sharp, 1943). When learning and teaching situations give the student pleasure, and when the learner can hear, see, feel or discover what he/she has achieved, his/her learning effort will be much stronger (Büyükkaragöz, Muşta, Yılmaz \& Pilten 1997). In addition, Aydın's (2012) study on how the geography courses should be taught to high school students particularly emphasized the need for "the use of visual technological elements in the geography lessons," which underscores the need for enhancing and supporting the geography course materials with technology.

\section{Suggestions}

In this study, the preservice teachers reported the geography course as necessary and highly important. However, since there are those who see the geography course as an unnecessary and low-importance course, the geography needs to gain the higher status it deserves. For this purpose, all stakeholders, including the relevant institutions and organizations are suggested to do their best to ensure that the status of geography among the sciences is appropriately established and secured, that the field does not fall in neglect, the due effort is exerted to make sure that the issues specifically related to the field of geography are not left to the care of other disciplines, that the necessary measures for the institutionalization of geography are taken, and that the importance of geography is recognized by all scientific communities.

Although the teacher candidates in this study stated that they use their geography knowledge in various places, care should be taken to explain what, where and when they will be needed by the instructors when transferring this information to them. This is because any information that is not used in daily life or that does not make our lives easier is considered unnecessary and is not valued. 
Although the concepts, phenomena, events and occurrences are transferred in the geography courses, the necessity of learning these and where they would be vitally important should be demonstrated to the students by showing examples.

Indisputably, the subject of geography has lost its reputation instead of earning a reputation today. One of the most important reasons for this is that geographical knowledge production does not meet the needs and demands of the society. Knowledge needs to be capable of meeting the needs of people and their needs. For this reason, the most important task of the geographers is that the knowledge they produce should be the kind that benefits the people or society.

When the preservice teachers' suggestions for teaching geography are examined, it is clear that they are aimed at problems that are known but not fully solved. The perception of a course where knowledge obtained from the geography courses is only transferred and memorized in the classroom has to be eliminated. For this, the suggestions of the students as the main stakeholders need to be taken into account.

\section{References}

Akınoğlu, O. (2005). The effectiveness and problems of geography education. Marmara Coğrafya Dergisi [Marmara Geography Journal], 12, 77-97.

Aydın, F. (2011). Secondary school students' opinions about geography course: a qualitative study. Archives of Applied Science Research, 3(1), 297-305.

Aydin, F. (2012). Social sciences highschool students opinions toward steaching of geography course. Kastamonu Ë̆itim Dergisi/ Kastamonu Education Journal, 20(3), 1035-1050.

Aydın, F., Kaya, H. \& Coşkun, M. (2011). The role of geography course in building environmental conscious. World Applied Sciences Journal, 12(6), 822-829.

Bakan, U. \& Bakan, U. (2017). A content analysis forthe investigation of family relation ships and social media engagement on facebook, Mehmet Akif Ersoy Üniversitesi Sosyal Bilimler Enstitüsü Dergisi, 9(20), 54-68.

Barth, J. L. \& Demirtaş, A. (1997). Primary school social studies teaching. Ankara: YÖK/Dünya Bankası Milli Eğitimi Geliştirme Projesi Hizmet Öncesi Öğretmen Eğitimi Yayınlar1.

Bent, G., Bakx, A., \& Brok, P. D. (2016). Comparison between primary teacher educators' and primary school teachers' beliefs of primary geography education quality. Australian Journal of Teacher Education, 41(7). 110-131.

Büyükkaragöz, S., Muşta, M., Yılmaz H. \& Pilten, Ö. (1997). Introduction to Education. Konya: Günay Ofset.

Coşkun, M. (2004). Cooperative (collaborative) learning in geography teaching. Kastamonu Eğitim Dergisi/Kastamonu Education Journal, 12(1), 235-237.

Demirci, A. (2004). Importance and method of using geographical information systems in primary and secondary geography courses: physical geography; gis-based example course on earthquake and volcanoes. Coğrafi Bilgi Sitemleri Biliş̧im Günleri, 6-9 Ekim: İstanbul. 
Demirci, A. (2005). The purpose of the globalized world in geography in turkey, methods and tools as self-questioning: what to do in geography education reform. Ulusal Cografya Kongresi, İstanbul.

Demirci, A., Sekin, S. \& Ünlü, M. (2002). The importance of geography in terms of occupation and lts usage in Turkey. Marmara Coğrafya Dergisi, 5, 171-185.

Dikmenli, Y. \& Çifçi, T. (2016). High school students' views about geography course. Turkısh Studies-International Periodical for the Languages, Literature and History of Turkish or Turkic, 11(3), 911-928.

Doğanay, H. (1993). Methodology in geography. İstanbul: MEB Yayınları.

Doğanay, H. (2002). Teaching methods of geography. Erzurum: Aktif Yayınevi.

Doğanay, H. \& Doğanay, S. (2015). General geography. Ankara: Pegem Yayıncılık.

Doğanay, H. \& Zaman, S. (2002). The objectıves- strategies and goals within secondary education geography teaching. Doğu Coğrafya Dergisi, 7(8),7-25.

Doğanay, H., (1989). Geography and geography teaching programs in our high schools. Coğrafya Araştırmaları Dergisi, 1(1), 7-25.

Elibüyük, M. (2000). Mathematical geography. Ankara: Ekol Yayıncılık.

Eyles, J. (1989). The geography of everyday life. D. Gregory et al. (eds.), In Horizons in human geography (102-117). London: Palgrave.

Girgin, M. (2001). Why we learn geography. Doğu Coğrafya Dergisi/ Eastern Geographical Review, 7(5), 127-143.

İzbırak, R. (1992). Dictionary of geography terms. MEB. Yayınları, İstanbul: Öğretmen Kitaplar1 Dizisi:157.

Johnston, R. J. (1985). Introduction: Exploring the future of geography. In the Future of Geography Ed. Johnston, R J, (Methuen, London) 3-26.

Karasar, N. (2015). Scientific research method - concepts, principles, techniques. Ankara: Nobel Yayıncilik.

Kenger, G. (2010). Determination of the level of association between geography concepts and everyday life that students in the 9th grade students learn in geography class. Yayınlanmamış Yüksek Lisans Tezi. İstanbul: Marmara Üniversitesi Sosyal Bilimler Enstitüsü.

Kesten, A. \& Özdemir, N. (2010). Evaluation of Social Studies Curriculum Assessment Part According to Opinions of Teachers: Case of Samsun. Firat Üniversitesi Sosyal Bilimler Dergisi, 20(2), 223-236.

Kızılçaoğlu, A. (2006). Geographic education in elementary schools. Marmara Coğrafya Dergisi, 14, 81-106.

Kocalar, A. O. \& Demirkaya, H. (2014). Why is geography 1mportant to learn? Perception of high school students. Doğu Coğrafya Dergisi/ Eastern Geographical Review, 19(32), 123-144.

Lacoste, Y. (1998). Geography is for fighting. (Çev. A. Ertan), İstanbul: Doruk Yayınları. 
MEB. (2017). Geography Course Curriculum. T.C. Millî Eğitim Bakanlığı Ortaöğretim Genel Müdürlüğü, Ankara.

Miles, M. B. \& Huberman, A. M. (1994). Qualitative data analysis (2nd Ed.). Thousand Oaks, CA: SAGE.

Ortaylı, İ. (2013). We are ignorant of geography. Tarihin Arka Odası Programı. (www.haberturk.com, 20.04.2018).

Öztürk Demirbaş, Ç. \& Dikmenli, Y. (2016). Geography teacher candidates' perceptions of being a geographer- II: physical properties. International Journal of Eurasia Social Sciences, 7(24), 75-98.

Reinfried, S. \& Hertig, P. (2011). Geographical Education: How Human Environment-Society Processes Work. In UNESCO-EOLSS Joint Committee (Ed.), Geography, encyclopedia of life supportsystems (EOLSS). Oxford.Erişim Tarihi: 11 June 2018. www.eolss.net.

Sack, D. \& Peterson, J. F. (1998). Children'sattitudes towards geograph: A Texas casestudy. Journal of Geograph, 97, 123-131.

Sharp, L. B. (1943). Outside the classroom. The Educational Forum, 7(4), 361-368.

Slater, F. (1994). Education through geography: Knowledge, Understanding, values and culture. Geography, 79 (2), 147-63.

Şahin, C. (2013). General geography. Ankara: Gündüz Eğitim Yayıncılık.

Şencan, H. (2005). Reliability and validity in social and behavioural measures. Ankara: Seçkin.

Tanrikulu, M. (2018). Geography and culture. Ankara: Pegem Akademi Yayınc1l1k.

Taşl1 Keçeci, Ö. (2010). Evaluation of the role of secondary education geography courses in creating environmental awareness to student topinions (Aydin province example). Yayınlanmamış Yüksek Lisans Tezi. Erzurum: Atatürk Üniversitesi Sosyal Bilimler Enstitüsü.

Tomal, N. (2009). Application of the knowledge acquired in geography lessons in dailylife. Kastamonu Eğitim Dergisi/Kastamonu Education Journal, 17(1), 229-240.

Ünlü, M., \& Alkış, S. (2006). Examining the necessity of geography instruction in the programs of pre school education departments. Marmara Coğrafya Dergisi, 14,17-27.

Yıldırım, A. \& Şimşek H. (2013). Qualitative research methods in the social sciences. (9. Baskı). Ankara: Seçkin Yayıncılık.

Yetim, A. A., \& Göktaş, Z. (2004). Teacher's occupational and personal qualifications. Kastamonu University Kastamonu Education Journal, 12(2), 541-550.

\section{Biographical Statements}

Taner ÇİFÇí is an associate professor at Sivas Cumhuriyet University. His areas of interest include value education and map literacy.

Yurdal DİKMENLİ is an associate professor at Kırşehir Ahi Evran University. His areas of interest include geographical literacy and disaster education. 